\title{
REGULAMIN PRZYZNAWANIA NAGRODY NAUKOWEJ PTN im. JÓZEFA BABIŃSKIEGO
}

Konkurs na Nagrodę Naukową im. Józefa Babińskiego został ustanowiony przez Walne Zgromadzenie Delegatów w 1980 r. podczas XI Zjazdu PTN w Bydgoszczy. Nagroda miała być przeznaczona dla: autora lub autorów najlepszei pracy oryginalnej, opublikowanej lub przygotowanej do publikacji w czasie trwania aktualnej kadencji Zarządu Głównego PTN, z dziedziny nauk neurologicznych, z wyraźną implikacia do neurologii klinicznej.

\section{Regulamin:}

1. Nagroda Naukowa im. Józefa Babińskiego jest przyznawana przez Zarząd Główny PTN na wniosek Komisji Nauki ZG dla autora lub autorów najlepszej pracy oryginalnej opublikowanej lub przyiętej do druku.

2. Prace przedstawiane do konkursu powinny być opublikowane lub zakończone w czasie trwania bieżącej kadencji ZG.

3. O nagrody moga ubiegać się członkowie PTN, kłórzy nie ukończyli 40. roku życia, bezpośrednio lub za pośrednictwem Instyłucji (Zarządy Oddziałów Terenowych PTN, Kierownicy Katedr i Klinik, Dyrektorzy Instytutów itp.).

4. Do konkursu nie moga być zgłaszane prace nagradzane już w innych konkursach.

5. Prace należy przesyłać $w 2$ egzemplarzach na ręce aktualnego Przewodniczącego Komisji Nauki ZG PTN, do 30 kwietnia roku Zjazdu Krajowego PTN.

6. Zarząd Główny może przyznać jedną lub więcej Nagród równorzędnych lub zrezygnować z przyznania Nagród.

7. Wysokość Nagród jest każdorazowo ustalana przez Zarząd Główny.

8. Nagrody sa wręczane podczas uroczystości otwarcia Zjazdu PTN.

9. Nazwiska laureatów nagród będq̨ opublikowane w Neurologii i Neurochirurgii Polskiej. 